\title{
Clinical approach to etiology, diagnosis, and treatment in dogs with pericardial effusion - a retrospective study
}

\author{
Meriç KOCATÜRK ${ }^{1}$, Hakan SALCI ${ }^{2}$, Volkan IPEK $^{3}$, Nureddin ÇELIMLİ ${ }^{2}$, Zeki YILMAZ $^{1}$ \\ Uludağ University, Faculty of Veterinary Medicine, ${ }^{1}$ Department of Internal Medicine, ${ }^{2}$ Department of Surgery, ${ }^{3}$ Department of \\ Pathology, Animal Hospital, Bursa, Turkey.
}

\begin{abstract}
Summary: In this study, signalement, presenting clinical signs, results of diagnostic investigations and therapeutic outcomes of $17 \mathrm{dogs}$ with pericardial effusion (PE) were evaluated retrospectively. Common findings were exercise intolerance (70\%), muffled heart sound $(60 \%)$ and ascites (50\%). ECG showed low voltage QRS (60\%) and supraventricular tachycardia (40\%). Radiological findings revealed enlarged and globoid cardiac silhouette in all dogs. PE was confirmed by echocardiographic examinations, which was due to intracardiac neoplasia $(n=6)$ or non-neoplastic causes [dilated cardiomyopathy $(n=5)$, right-sided heart failure (RSHF, $\mathrm{n}=2$ ), and idiopathic $(\mathrm{n}=4)$ ]. In dogs with RSHF, Doppler-derived pulmonary hypertension was also observed. Analysis of pericardial fluids that was collected by pericardiocentesis showed a hemorrhagic effusion in dogs with intracardiac neoplasia, and transudate in the rest. In 4 dogs with neoplastic PE, pericardiectomy and tumor resection were performed. Histopathological examinations revealed an aortic body adenoma $(n=1)$, aortic body carcinoma $(n=1)$, papillary mesothelioma $(n=1)$ and malignant epitheloid mesothelioma $(n=1)$. In 2 dogs, neoplastic PE could not be classified. Dogs were treated medically for heart failure and neoplasia, as well. Prognosis was better for the first 12 months in dogs with non-neoplastic PE. In conclusion, echocardiographic examination is the best means to diagnose PE. In practice, when added to physically examination findings echocardiography also provides solid information in determining prognosis of PE due to neoplasia versus non-neoplastic causes. Survival time may be extended by pericardiectomy in the case of neoplastic PE, as well.

Keywords: Echocardiography, electrocardiography, pericardial effusion, pericardiectomy, dog.
\end{abstract}

\section{Perikardiyal efüzyonlu köpeklerde etiyoloji, tanı ve tedaviye klinik yaklaşım - retrospektif bir çalışma}

Özet: $\mathrm{Bu}$ çalışmada, retrospektif olarak perikardiyal efüzyonlu (PE) 17 köpeğin signalement, klinik bulgu, diagnostik araştırma ve terapötik sonuçları ele alınmıştır. PE intrakardiyak neoplazi $(n=6)$ veya non-neoplastik nedenlerden [dilate kardiomiyopati $(\mathrm{n}=5)$, sağ kalp yetmezliği $(\mathrm{RSHF}, \mathrm{n}=2)$ ve idiopatik $(\mathrm{n}=4)]$ ileri gelmişti. Yaygın bulgular egzersiz intoleransı $(\% 70)$, boğuk kalp sesleri $(\% 60)$ ve asitesti $(\% 50)$. Elektrokardiyografik olarak düşük voltajlı QRS (\%60) ve supraventriküler taşikardi (\%40) belirlendi. Ekokardiyografi ile PE olduğu doğrulanan tüm köpeklerde, radyolojik bulgular kalbin büyük ve globoid olduğunu gösterdi. RSHF'li köpeklerde, Doppler-derive pulmonar hipertansiyon belirlendi. Perikardiyosentezle alınan sıvı analizleri kardiyak tümörlü köpeklerde hemorajik efüzyonu, diğerlerinde ise transudat varlı̆̆ını gösterdi. Neoplastik PE'lu 4 köpekte perikardiyektomi ve tümör rezeksiyonu yapıldı. Histopatolojik muayeneler aortik body adenom $(n=1)$, aortik body karsinom ( $n=1)$, papillar mesoteliom ( $n=1)$ ve malignant epiteloid mesoteliomu $(n=1)$ gösterdi. İki köpekte neoplastic PE sinıflandırılamadı. Köpekler etiyolojilerine göre medical olarak tedavi edildi. Non-neoplastik PE’li köpeklerin prognozları ilk 12 ay için daha iyiydi. Sonuç olarak, ekokardiyografik muayene PE tanısında en iyi yöntemdir. Pratikte fiziksel muayene bulguları ile birlikte değerlendirildiğinde ekokardiyografi neoplazik ve neoplazik olmayan PE’lerin prognozunun belirlenmesinde önemli katkılar sağlamaktadır. Neoplastik PE olgularında perikardiyektomi yaşam süresinin uzatılmasına katkı verebilir.

Anahtar sözcükler: Ekokardiyografi, elektrokardiyografi, perikardiyal efüzyon, perikardiyektomi, köpek.

\section{Introduction}

Pericardial effusion (PE) is the abnormal accumulation of fluid within the pericardial space $(18$, 23). It is the most common disease of the pericardium in dogs (18). Small volumes of PE may not cause clinical signs; however, as the volume and pressure in the pericardial space increase, cardiac tamponade can develop. The most common causes of PE in dogs are cardiac neoplasia, right-sided heart failure, cardiac rupture and idiopathic pericarditis and less commonly congenital pericardial disorders, trauma, or infectious processes. In dogs, neoplastic PE is commonly related with hemangiosarcoma (HSA), chemodectoma, and mesothelioma, and less commonly related with ectopic thyroid carcinoma, lymphosarcoma, and myxosarcoma $(8,18)$.

Common physical findings were muffled heart sounds, jugular venous distention, tachycardia, abdominal 
distension, and tachypnea in dogs (4, 18, 22). Radiography is generally considered an insensitive indicator in deducting the cause of effusion although it might detect the pulmonary masses, which represent the primary cardiac tumors (17). The cardiac shape frequently appears globoid or rounded on thoracic radiographs. It is not unusual for $\mathrm{PE}$ to be mistaken for dilated cardiomyopathy (DCM). Pleural effusion may also be noted on radiographs. Caudal vena cava distention, hepatomegaly, ascites, and pleural effusion may be present if the patient has developed congestive heart failure $(4,18)$. Common electrocardiographic (ECG) findings in patients with PE include sinus tachycardia, ventricular arrhythmias, low-voltage QRS complexes, and ST segment elevation, as well as electrical alternans $(13,22,23)$.

For the past several years, the echocardiogram has been the diagnostic test of choice in cases of PE. It is noninvasive and can provide much more information than radiography because it can distinguish the pericardium, pericardial fluid, and heart, structures that are indistinguishable on a radiograph. Because echocardiography is such a sensitive and specific method, it can detect even a small amount of PE. The PE itself is helpful during echocardiography because it often acts as a contrast medium to help visualize a cardiac mass if present $(4,7,14)$. Pericardiocentesis is indicated as an emergency treatment of cardiac tamponade. Pericardiectomy can be definitive treatment of idiopathic $\mathrm{PE}$ and a palliative treatment of malignant PE $(9,14,18$, 20). Chemotherapy may be useful in some cases of malignant PE. The prognosis for dogs with PE varies greatly (1 month to 2 years), depending on the underlying cause $(12,18)$. Although the prognosis for dogs with PE due to HSA is generally poor, idiopathic PE has a good to excellent prognosis (22). The aim of our study was to discuss the retrospectively collected data of our patients with PE in comparison with literature information and to draw attention at the importance of PE. Diagnostic, therapeutic and prognostic approaches in dogs with neoplastic and non-neoplastic PE were evaluated, as well.

\section{Materials and Methods}

Dogs: The case records of all dogs with PE between January 2006 and December 2014 at the Small Animal Clinic - Cardiology Unit (Veterinary Medicine, Uludag University, Bursa-Turkey) were retrospectively reviewed. The records were examined for signalement, history, diagnostic tests, pericardiocentesis, and follow-up information on the outcomes. Dogs with PE due to cardiac neoplasia or secondary to other recognized causes (dilated cardiomyopathy-DCM, right-sided heart failure-RSHF, and idiopathic) were included. Cases with traumatic PE were excluded.
Clinical examinations: All dogs underwent a routine physical examination. Temperature, heart and respiratory rates, and peripheral pulse quality were recorded for this study. Thoracic radiographs were obtained in dorsoventral and right lateral views. Vertebral heart score was measured as suggested (7). ECG parameters were recorded in dogs in right lateral recumbency. Cardiac rhythms were analyzed on lead II $(50 \mathrm{~mm} / \mathrm{s} ; 10 \mathrm{~mm} / \mathrm{mV})$ (15). Abdominal ultrasonography was carried out during diagnostic work-up, as well. Only for 2 cases, tomographic examinations could be performed to anatomical localization of cardiac neoplasia (3) in the private medical hospital. Invasive or non-invasive blood pressure measurement could not be performed in all cases.

Definition of pericardial effusion (PE): PE was defined and then classified on the diameter of echo-free space between parietal and visceral pericardium, as mild $(<1.0 \mathrm{~cm})$, moderate $(1.0-2.0 \mathrm{~cm})$ and severe $(>2.0 \mathrm{~cm})$, by use of M-Mode echocardiography on the right parasternal short axis view - papillary muscle level (16). Dimensions of effusions were calculated as a mean of three consecutive measurements during diastole. To avoid or minimalize the respiratory stress, as an emergency procedure, pericardiocentesis was performed with guidance of a transthoracic ultrasonography and simultaneously ECG. Thereafter routine echocardiographic measurements were performed.

Echocardiographic measurements: Echocardiograms were reviewed to assess the cardiac geometry and function, as suggested $(5,22)$. For this purposes, dogs were positioned to the right lateral recumbency on the table designed for cardiological examination. All echocardiograms were performed in conscious unsedated dogs during a period of quiet respiration. Twodimensional (2-D), M-Mode, color flow and Doppler echocardiography were performed subsequently using conventional clinical echocardiographic equipment (Caris Plus, Esoate, Italy) with phased array electronic transducers $(2.5-10 \mathrm{MHz}$ ). Left ventricle (LV) and LVrelated parameters (LV diameters and interventricular septum [IVS] and LV free-wall thickness at diastole and systole) were measured for each patient by M-mode on the right parasternal long axis view, fractional shortening (FS) and ejection fraction (EF) were estimated automatically after LV dimensions and IVS thickness were provided. Left atrium (LA), aorta (Ao) and pulmonary artery dimensions were measured on the right parasternal short axis view - Ao level.

Atrioventricular and semilunar valves were examined by color flow and then spectral Doppler echocardiography was performed to analysis blood flow and (if present) regurgitant jet velocity. Pulmonary artery systolic pressure (PASP) was calculated by adding the transtricuspid pressure gradient to the right atrial pressure - $10 \mathrm{mmHg}$ (19). Transtricuspid pressure gradient was 
calculated using the modified Bernoulli equation $\left(4 \mathrm{v}^{2}\right)$ where $\mathrm{v}$ is the maximum velocity of the tricuspid valve regurgitant jet (TRJ). TRJ was examined on the left parasternal apical 4-5 chamber view - Doppler cursor was placed at the point of maximal regurgitant jet area under the tricuspidal valve. All geometric and functional parameters obtained from echocardiographic measurements in dogs were compared with reference ranges showing a variation based on the breed and body weight (5). DCM was diagnosed based on the increased LV diastolic and systolic dimensions, increased $\mathrm{E}$ point to septal separation (EPSS) and decreased FS $(<25 \%)$ in dogs. RSHF was diagnosed in dogs with ascites and jugular distension, depends on the increased right atrial (RA) and right ventricular (RV) dimensions (5).

Laboratory measurements: Blood samples for haematology (HM5, Abaxis) and serum biochemistry (VetScan, Abaxis) were obtained prior to diagnostic procedures. WBC and platelet counts, hematocrit (Hct), and serum albumin were used in this study. Abdominocentesis and pericardiocentesis were performed, as suggested (14). Ascitic and pericardial fluids were analyzed by a commercial multistix (Combur 10, Roche), and then were stained with diff quick for cytological examinations. Ascitic fluids were characterized transudate based on the low specific gravity, alkaline $\mathrm{pH}$, and negative protein, keton, nitrat, nitrit, hemoglobin and blood cell, or modified transudate based on the low specific gravity, alkaline $\mathrm{pH}$, and mild to moderate protein and WBC content. Hemorrhagic effusions were characterized by the red color appearance - similar to blood and high RBC content (22).

Surgical and medical management: After the diagnosis of PE, four of the owner accepts the surgical procedure - pericardiectomy and tumor resection in the cases of hemorrhagic PE due to intra-cardiac neoplasia. General anesthesia of the dogs was performed by the combination of ketamin $\mathrm{HCl}$ and diazepam. After intratracheal intubation, general anesthesia was maintained with $2 \%$ isoflurane. Monitorisation of the dogs during surgery was provided with pulse oximetry, capnography, $\mathrm{SpO}_{2}$, ECG, $\mathrm{CVP}$, blood gas and coagulation analysis, noninvasive blood tension. Respiration was assisted by mechanic ventilation when the pleural spaces of the dogs were opened. Intercostal right easily exposed the intrathoracic organs or left thoracotomy and then pericard was incised under the phrenic nerve line to approach the hearth and tumor on hearth or aorta and to see the clearly vascular structures. Tumoral masses were excised carefully and then pericardial sac was removed with subtotal pericardectomy technique. After surgical excisions, a suitable size of thoracostomy tube was inserted and then Heimlich valve drainage was maintained to evacuate the intrapleural residual air and/or fluids. Thoracic cavity was closed routinely.
Medical therapy protocol was suggested for all. Idiopathic and neoplastic PE were treated with a combination of ampicillin $(10 \mathrm{mg} / \mathrm{kg}, 2 \times 1$, i.m.), and prednisolone (1-2 mg/kg, 2x1, i.m., po). In the cases of neoplastic PE, prednisolone therapy as a single chemotropic agent was continued with its maintenance dosage $(1 \mathrm{mg} / \mathrm{kg}$ alternate day, and then lowering dosage and expanded time intervals) during 2 months after surgery. Dogs with congestive heart failure due to DCM or RSHF received pimobendan (0.2-0.5 mg/kg/day, po) or digoxin $(0.005 \mathrm{mg} / \mathrm{kg}$, po, 2x1) with or without a calcium channel blocker (diltiazem, $0.5 \mathrm{mg} / \mathrm{kg}, 2 \times 1$, po), enalapril $(0.5-1 \mathrm{mg} / \mathrm{kg}, 2 \times 1$, po), and furosemide (2-4 $\mathrm{mg} / \mathrm{kg}, 2 \mathrm{x} 1$, po), as suggested $(1,22)$. Furosemide was administered after pericardiocentesis. Follow up evaluations were provided by repeated examinations in Animal Hospital or by the phone call of the owner.

Histopathological examinations: Tissue samples were taken into formalin and they were sectioned at 5 micrometer thickness after following routine tissue processing procedures. Slides were stained with $\mathrm{H} \& \mathrm{E}$ and examined in light microscope.

Statistical analysis: Descriptive statistics were performed to obtain mean, and maximum and minimum values for selected parameters (Sigma Stat 2.0, GmbH, Germany). An association between left ventricular ejection fraction and fractional shortening and diastolic dimension of PE was examined by Pearson product moment correlation. Survival times of dogs with neoplastic or non-neoplastic PE were compared by Student $\mathrm{t}$ test. $\mathrm{P}$ value less than 0.05 was considered significant.

\section{Results}

Clinical findings: In this study, 8 male and 9 female dogs of different breed (Terrier 5, German shepherd 3, Pointer 3, Anatolian sheepdog 3, Dogo argentina, Great dane, Pekingese), age (mean: 10.9 yrs; min.: 9 months; max.: $15 \mathrm{yrs}$ ), and body weight (mean: $23.8 \mathrm{~kg}$; min.: 3 kg; max.: $85 \mathrm{~kg}$ ) were evaluated. Common physical findings were exercise intolerance $(70 \%)$, muffled heart sound $(60 \%)$, weak peripheral pulse quality (60\%), ascites $(50 \%)$ and coughing $(30 \%)$. Mean temperature and heart and respiratory rates were $38.7 \pm 0.6{ }^{\circ} \mathrm{C}, 168 \pm$ $20 \mathrm{bpm}$, and $44 \pm 7$ breaths/min., respectively.

In the case of mild PE, dogs showing the compatible signs of DCM and RSHF had low-intensity heart murmur at mitral and tricuspid valve puncta maxima. ECG showed low voltage of QRS complexes (60\%), supraventricular tachycardia (40\%), ST segment elevation (20\%) and electrical alternans (20\%) (Figure 1). Radiological findings revealed increased sternal attachment of heart, enlarged heart size (mean vertebral heart score: $11.6 \pm 0.3$ ), globoid or rounded cardiac shape and elevation of the trachea in all dogs. Caudal vena cava 
distention, alveolar pattern and lung edema were also determined. Ascites and hepatomegaly were confirmed by the abdominal ultrasonography in dogs with RSHF. In the case of aortic body carcinoma, within 3 months after pericardioctemy, pleural effusion and lung edema were observed on computed tomography (Figure 2).

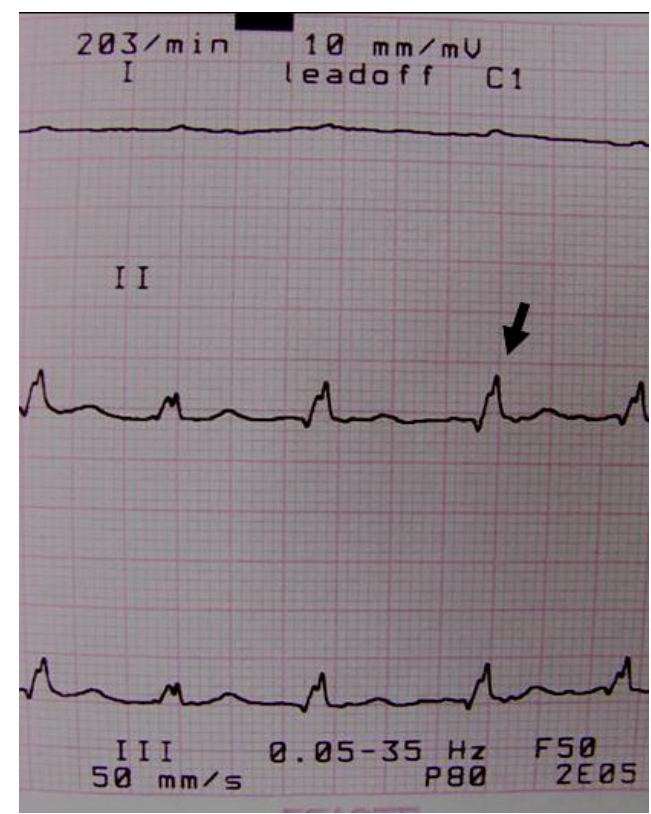

Figure 1: A low voltage QRS (R wave: $0.5 \mathrm{mV}$; black arrow), slight electrical alternans and atrial fibrillation in a dog with PE due to dilated cardiomyopathy.

Şekil 1: Dilate kardiyomyopatiye bağlı perikardiyal efüzyonlu köpekte küçük kompleks QRS (R dalgasi: $0.5 \mathrm{mV}$; siyah ok), hafif elektrik alternans ve atriyal fibrilasyon.

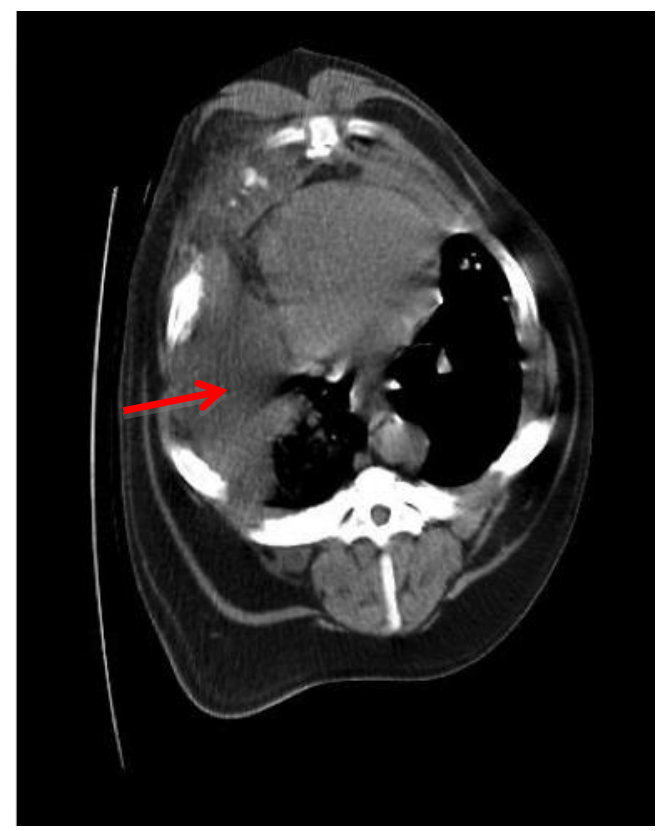

Based on the echocardiographic examinations, as reasons for PE, intracardiac neoplasia $(n=6), D C M(n=5)$ and RSHF ( $n=2)$ were observed, but PE was idiopathic in 4 dogs (Figure 3). Intra-cardiac neoplasia was confirmed as an aortic body adenoma $(\mathrm{n}=1)$, aortic body carcinoma $(n=1)$, well differentiated papillary mesothelioma $(n=1)$ and malignant epitheloid mesothelioma $(n=1)$ by histopathological findings in the biopsy samples in 4 cases (Figure 4). However, in 2 cases, owner did not give permission to surgery, therefore those cases were accepted as having an un-differentiated neoplastic PE. 2$\mathrm{D}$ and M-mode echocardiography showed dilated LV, decreased FS and increased EPSS in dogs with DCM, or dilated RV and RA in dogs with RSHF, or normal variation of cardiac cambers measurements in dogs with idiopathic PE (Table 1). Also when the dog had the reference levels in serum liver enzyme activities (ALT, AST and ALP) and renal injury markers (BUN and Cr) as well as serum total protein and albumin levels (data not shown), PE was defined as idiopathic. Tricuspid regurgitation (TR) and then Doppler-derived pulmonary hypertension were detected in 2 dogs with RSHF in which maximal velocity (Vmax) of TR was of $3.73 \mathrm{~m} / \mathrm{s}$ (estimated PASP $=65 \mathrm{mmHg}$ ) and $4.65 \mathrm{~m} / \mathrm{s}$ (estimated $\mathrm{PASP}=96 \mathrm{mmHg}$ ). In 6 out of 17 dogs with PE, cardiac tamponade was easily confirmed by 2-D echocardiography, include RA compression during late diastole, RV collapse during early diastole, dilated inferior vena cava with lack of inspiratory collapse and swinging heart. Diameters of PE (median: $2.5 \mathrm{~cm}$, max.: $3.8 \mathrm{~cm}$ and min.: $1.3 \mathrm{~cm})$ were of $<1 \mathrm{~cm}(\mathrm{n}=5), 1-2 \mathrm{~cm}(\mathrm{n}=6)$ and $>2 \mathrm{~cm}$

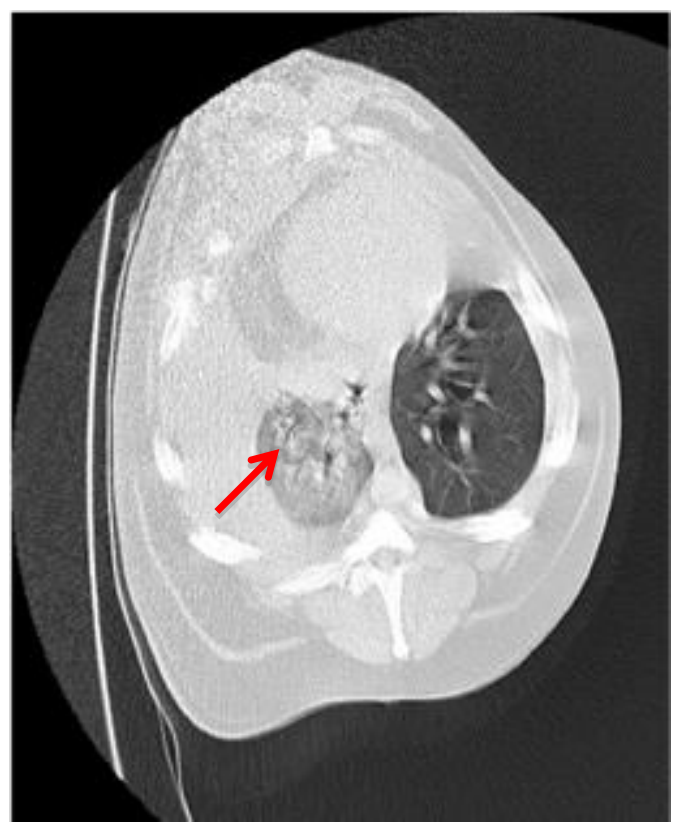

Figure 2: Left - computed tomographic views of the case with pericardial effusion. It is pointed out the right pleural effusion (arrow) and compressed lung areas in the left hemithorax. Right - lung window view also shows the pulmonary edema (arrow) in the compressed lung.

Şekil 2: Sol - perikardiyal efüzyonlu olgunun bilgisayarlı tomografi görüntüsü. Sağ pleural efüzyon (ok) ve sol hemitoraksta baskılanmış akciğer alanları görülmekte. Sağ - akciğer penceresinde pulmoner ödem görünümü (ok). 

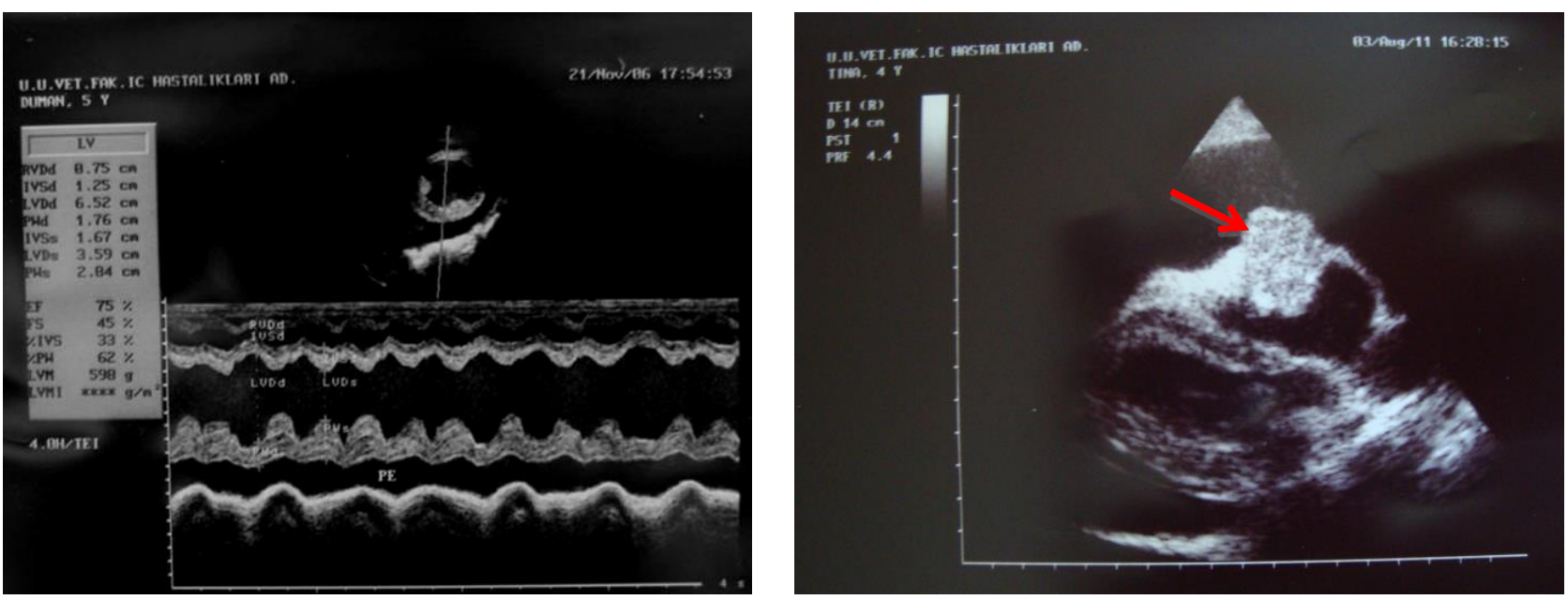

Figure 3: Left - pericardial effusion (PE), M-mode measurement in a dog with dilated cardiomyopathy. Right - circular mass on the right atrium in the pericardial sac with effusion.

Şekil 3: Sol - perkardiyal efüzyon (PE), M-mode görünüm - dilate kardiyomyopatili bir köpek. Sağ - perikardial kese içinde, efüzyon ile birlikte sağ atrium üzerinde sirküler kitle.

Table 1: M-mode echocardiographic measurements from dogs with pericardial effusion. Tablo 1: Perikardiyal efüzyonlu köpeklerde M-mode ekokardiografik ölçümler.

\begin{tabular}{lccc}
\hline Parameters (cm) & Mean $\pm \mathrm{Sd}$ & Minimum & Maximum \\
RVD & $1.1 \pm 0.5$ & 1.2 & 1.8 \\
IVSDd & $1.2 \pm 0.4$ & 0.6 & 1.6 \\
IVSSd & $1.5 \pm 0.3$ & 0.9 & 6.5 \\
LVDd & $3.3 \pm 2.3$ & 2.1 & 3.6 \\
LVSd & $2.0 \pm 0.9$ & 8 & 1.8 \\
PWDd & $1.0 \pm 0.3$ & 0.7 & 2.2 \\
PWSd & $1.5 \pm 0.4$ & 0.9 & 24 \\
FS \% & $20 \pm 5$ & 13 & 41 \\
EF \% & $34 \pm 6$ & 30 & 2.4 \\
Left atrium & $2.1 \pm 0.2$ & 1.6 & 2.1 \\
Aorta & $1.8 \pm 0.3$ & 1.4 & 2.2 \\
\hline Pulmonary artery & $1.9 \pm 0.3$ & 1.5 & \\
\hline RVDd: right venticurat
\end{tabular}

RVDd: right ventricular diastolic dimension; IVSDd: Thickness of the interventricular septum (IVS) in diastole; IVSSd: Thickness of the IVS in systole; LVDd: left ventricular internal diameter (LVID) in diastole; LVSd: LVID in systole; PWDd: Thickness of the LVFW in diastole; PWSd: Thickness of the LVFW in systole.

$(n=6)$. There was a negative correlation $(\mathrm{p}<0.001$, $r=-0.971$ for $F S$ and $r=-0.972$ for $E F$ ) between functional cardiac parameters and systolic diameter of PE in all dogs.

Laboratory findings: Pericardial fluids from dogs with cardiac neoplasia were characterized by hemorrhagic effusion. Mean packed cell volume of the hemorrhagic effusions was $20 \pm 3 \%$ (rarely clots). Neoplastic cells could not be detected by cytological examinations in pericardial fluids. In non-neoplastic cases, effusions were characterized as transudate $(n=5)$ or modified transudate $(n=6)$, according to without cellular and chemical contents, and Diff-quick stain results. There were not bacteria and neoplastic cell in abdominal and pericardial fluids. In dogs with PE, mean WBC count, Hct, and platelet count were $14.200 / \mu 1,35.8 \%$, and $336.000 / \mu 1$, respectively. Serum albumin levels were between $2.8 \mathrm{gr} / \mathrm{dl}$ and $3.5 \mathrm{gr} / \mathrm{dl}$ in dogs.

Histopathological findings: Two of tumors were diagnosed as aortic body tumor. Microscopically, tumor cells were arranged in sheets or nests separated by fibrovascular connective tissues (Figure 4A). The cytoplasm of the tumor was polyhedral lightly eosinophilic. The cytoplasmic lines were usually indistinct. Nuclei were round and centrally located. Giant cells were frequently observed among to tumoral cells. In the other two malignant aortic body tumors, microscopically, intravascular invasion, numerous mitotic figures and increased blood supply were accompanied with benign findings mentioned above (Figure 4B). 

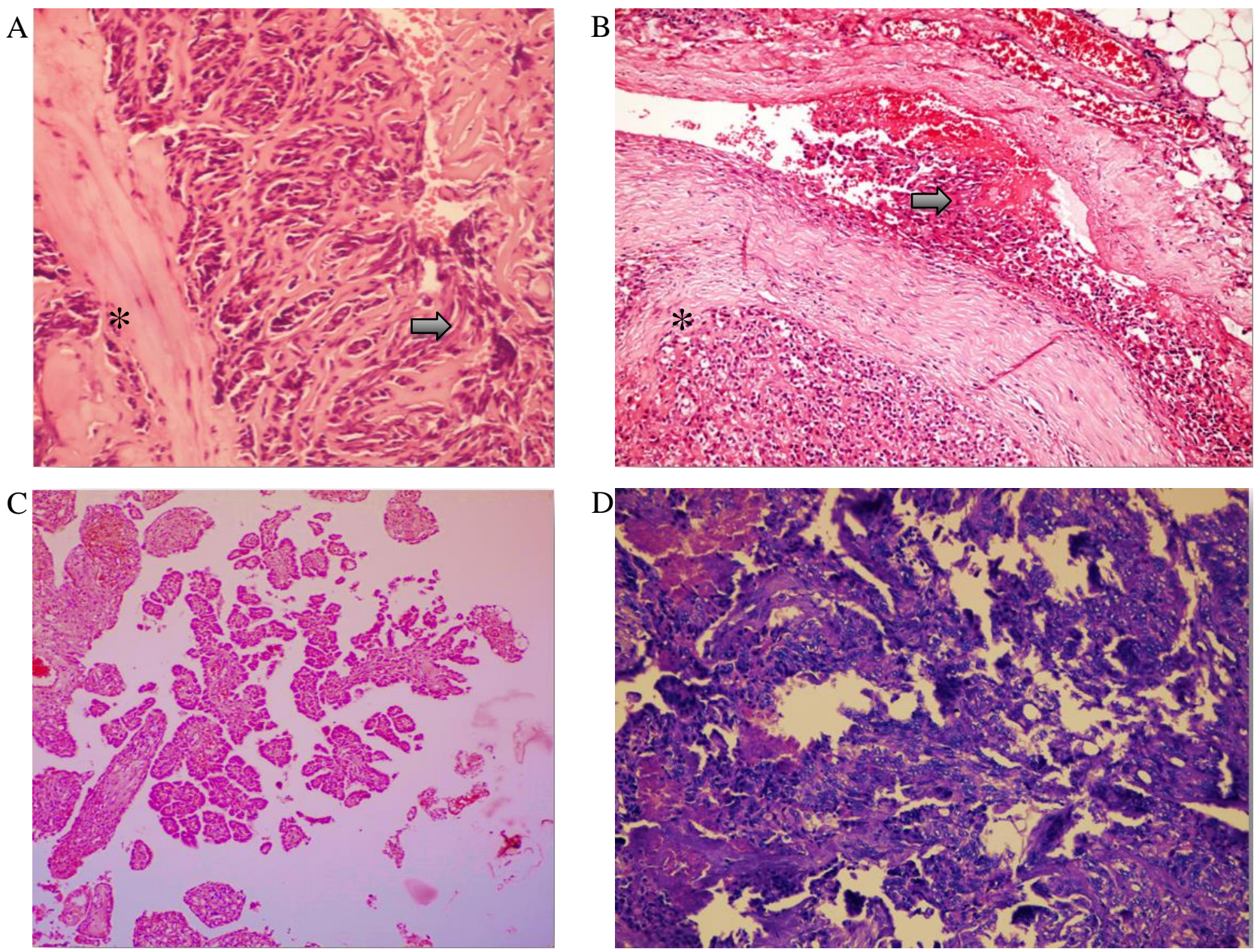

Figure 4. Histopathological findings from dogs with pericardial effusions due to heart base tumors.

Şekil 4. Kalp tümörüne bağlı perikardiyal sıvı gelişen köpeklerde histopatolojik bulgular.

A: Aortic body adenoma - tumor cells separated by fibrovasculary connective tissue (asterisk) and giant cell formations (arrow). B: Aortic body carcinoma - highly vascular tumoral tissues separated by fibrovasculary connective tissue (asterisk) and vascular invasion of neoplastic cells (arrow). C: Well differentiated papillary mesothelioma - papillary projections of mesothelial cell nests. D: Malignant epitheloid mesothelioma - multilayered epithelioid cell nests with tubular and solid areas.

Two mesothelioma were named as well differentiated papillary mesothelioma and malignant epithelioid mesothelioma. In the benign tumor, microscopically tumor has the typical features described for welldifferentiated papillary mesothelioma (a papillary architecture, nests and individual cells, bland mesothelial cells, absent mitotic figures) (Figure 4C). In the malignant one, the tumor consisted of multilayered nests of epithelioid cells with tubular formation and solid areas. Tumor cells were round with round nuclei and distinct nucleoli. Moderate anisokaryosis and some polygonal cells were observed. Mitotic figures were frequent (Figure 4D).

Outcome: Dogs with intracardiac neoplasia did respond for short time to pericardiocentesis, tumor extirpation and medical treatment. Prognosis was better for the first 12 months in dogs with non-neoplastic PE. Mean survival time was $246 \pm 231$ days for all dogs: it was $135 \pm 47$ days and $405 \pm 167$ days $(\mathrm{P}<0.01)$ in dogs with neoplastic and non-neoplastic causes, respectively. After the surgery, dogs with neoplastic effusion survived for 6 months (Aortic body adenoma), 3 days (aortic body carcinoma), < 1years (mesothelioma). Overall mortality and morbidity were $40 \%$ and $20 \%$ for dogs with neoplastic PE and 18\% and 10\% for dogs with nonneoplastic PE, respectively.

\section{Discussion and Conclusion}

In the study, PE due to intracardiac neoplasia and non-neoplastic causes was diagnosed in medium- and large-sized dogs, >10 yrs, and both gender, in agreement with the previous reports $(7,14)$. Although no single clinical finding is pathognomonic for $\mathrm{PE}$, in the present study, a combination of exercise intolerance, muffled heart sound, ascites with or without jugular distension, coughing, and weak peripheral pulse quality was indicative of the presence of PE $(14,24)$. Although ECG findings are not pathognomonic for $\mathrm{PE}$, they can be very 
indicative of the presence of PE. In our study, the most common ECG abnormality was low voltage QRS, probably due to mechanicoelectrical alterations of the myocardium, distance of the heart from body surface electrodes and reduction of cardiac size and volume (6, 22). A possible reason why the electrical alternans was so uncommon in this study may be that it is rate dependent and is likely to occur at relatively normal heart rates in dogs (7). Observed ST-segment elevation in dogs studied may be resulting from pericardial injury, pericarditis (14), and myocardial involvement (6).

Our findings were compatible with other study reporting that enlargement and rounded of the cardiac silhouette are commonly observed on thoracic radiographs in dogs with $\mathrm{PE}(10,17,22)$. Cote et al. (11) reported that the sensitivity and specificity of enlargement of the cardiac silhouette (vertebral heart score $\geq 10.7$ ) for identification of dogs with PE were $77.6 \%$ and $47.8 \%$, respectively. Guglielmini et al. (13) reported that objective radiographic indexes of cardiac size and roundness were only moderately accurate at distinguishing dogs with PE from dogs with other cardiac disorders without PE. Pulmonary vascularity is often reduced from low cardiac output in cardiomyopathy. In this study, observed increase in pulmonary interstitial densities, distension of the caudal vena cava and hepatomegaly may be due to RSHF, in consistence with the previous reports $(7,18)$.

In this study, all dogs were examined by use of echocardiography, to confirm the presence of $P E$. Also, in two dogs suspected from neoplastic PE, tomography was performed to confirm the neoplastic mass and its extent, anatomic location and potential type. In all dogs, abnormal fluid accumulation in different severity was observed as a sonolucent space between the epicardium and pericardium, extending from apex to base. In 6 dogs, PE was secondary to cardiac neoplasia localized in the $\mathrm{RV}$ and around the aorta, without leading to RSHF. In small animals, the incidence of cardiac neoplasia is low, and HSA is the most common type of cardiac neoplasia $(14,22)$. A cavitated, soft tissue mass arising from the RA is thought to be a HSA. A mass arising from and encircling the ascending aorta is likely a heart-base tumor $(14,24)$. A dog with clinical signs of RSHF was reported to have PE due to HSA occupying the RA and RV lumens (24). Primary cardiac lymphosarcoma (15), lymphoma $(21)$, and mesothelioma $(13,14)$ give rise to PE in dogs, as well. In the present study, aortic body tumor $(n=2)$ and cardiac mesothelioma $(n=2)$ were defined arising from RA or encircling the ascending aorta in parallel to literature information $(13,14)$.

In the early phase of DCM, the left side of the heart is more affected than the right but over time backward failure may occur resulting in biventricular failure (7, 22). In this study, RSHF was characterized by jugular venous distention, lacking of inferior vena cava inspiratory collapse, ascites and hepatomegaly, and enlargement of right cardiac chambers in 2 dogs. PE may also be a manifestation of RSHF (23). The physiology of the formation and removal of pericardial fluid is incompletely understood. However, fluid resorption is probably via an extensive venous circulation and a system of lymphatic plexuses that are located in the subepicardial region of the heart. These ultimately drain into the RA $(16,18,23)$. Thus, in this study, it is likely that the PE in dogs with RSHF or DCM was due to impaired venous and lymphatic drainage (passive congestion) resulting from elevated RA pressure $(16,18)$. Elevated pulmonary arterial pressures results in remodeling and enlargement of the RA and RV, leading to subsequent RSHF. PE has been noted to complicate pulmonary hypertension (PH) in up to $54 \%$ of human patients (16), but the relationship of $\mathrm{PE}$ and $\mathrm{PH}$ in dogs is not well known yet (19).

M-mode and 2-D echocardiographic evaluation of diastolic collapse of the RA and RV free walls are accepted signs of cardiac tamponade. Cardiac tamponade occurs when the intrapericardial pressure equals or exceeds RV diastolic filling pressure leading to a decreased cardiac output $(20,22)$. In this study, alterations of functional cardiac parameters (decreased EF and FS), especially in the presence of large volume of PE were noted as indicators of decreased cardiac output (6). It rarely results in a volume large enough to cause tamponade and require pericardiocentesis $(18,22)$. In this study, diagnostic pericardiocentesis showed hemorrhagic $\mathrm{PE}$ in 6 dogs with neoplasia and transudate or modified transudate in the rest. Transudative ascitic fluids and PE have been reported to induce by congestive heart failure and hypoalbuminemia, but hemorrhagic PE is frequently induced by cardiac neoplasia or idiopathic causes (4). In the study, none of the dog had an exudative PE that can be a result of an infectious pericarditis (4).

Thoracoscopic pericardial window is of low mortality with short surgery and hospitalization times. It provides good long-term control of idiopathic PE but short-term palliation of clinical signs in dogs with neoplastic disease (2). However, that dogs with idiopathic PE treated with a subtotal pericardectomy via thoracotomy had a significantly longer mean survival time, compared with dogs treated by the thoracoscopic pericardial window procedure was reported (9). Although pericardiectomy has been reported to definitive treatment of neoplastic and idiopathic PE $(14,18)$, four of the owner accepted the surgical procedure in the study. Thus, after the final diagnosis of PE, symptomatic treatment protocol for PE and specific treatment for the underlying condition (corticosteroid for neoplasia, and pimobendan, furosemide and enelapril for DCM) were initiated, as suggested $(18,22)$. It was reported that the prognosis in 
dogs with PE due to HSA was poor, but dogs with idiopathic PE had a good to excellent prognosis (18). In this study, survival time in dogs with neoplasia was lower than that of dogs with DCM and RSHF, suggesting that prognosis was better for the first year in dogs with non-neoplastic PE. Median survival time was reported to 15.3 months for dogs with idiopathic PE, and 16 days for dogs with cardiac neoplasia (13). In this study, surgery was suggested in order to extent survival time for dogs with neoplastic PE, and maximum survival time was observed ( $>1$ year) in dogs operated for cardiac mesetholima. This suggests that surgery may be a good choice for cardiac mesothelioma.

In conclusion, echocardiographic examination is essential to diagnose and manage PE. In practice, when added to clinical examination findings echocardiography also provides solid information in determining prognosis of PE due to neoplasia versus non-neoplastic causes.

\section{References}

1. Adeyanju JB, Perry R, Yakubu AS, et al. (2012): Idiopathic pericardial effusion in 2-year-old labrador managed with ultrasound-guided pericardiocentesis: Case report. Sokoto J Vet Sci, 10, 36-39.

2. Atencia S, Doyle RS, Whitley NT (2013): Thoracoscopic pericardial window for management of pericardial effusion in 15 dogs. J Small Anim Pract, 54, 564-9.

3. Boddy KN, Sleeper MM, Sammarco CD, et al. (2011): Cardiac magnetic resonance in the differentiation of neoplastic and nonneoplastic pericardial effusion. J Vet Intern Med, 25, 1003-9.

4. Bonagura JD, Pipers FS (1981): Echocardiographic features of pericardial effusion in dogs. J Am Vet Med Assoc, 179, 49-56.

5. Boon JA (1998): Manual of Veterinary Echocardiography. 356-371. Williams and Wilkins, Baltimore.

6. Bruch C, Schmermund A, Dagres N, et al. (2001): Changes in QRS voltage in cardiac tamponade and pericardial effusion: reversibility after pericardiocentesis and after anti-inflammatory drug treatment. J Am Coll Cardiol, 38, 219-226.

7. Buchanan JW, Bucheler J (1995): Vertebral scale system to measure canine heart size in radiographs. $\mathrm{J}$ Am Vet Med Assoc, 206, 194-199.

8. Cagle LA, Epstein SE, Owens SD, et al. (2014): Diagnostic yield of cytologic analysis of pericardial effusion in dogs. J Vet Intern Med, 28, 66-71.

9. Case JB, Maxwell M, Aman A, et al. (2013): Outcome evaluation of a thoracoscopic pericardial window procedure or subtotal pericardectomy via thoracotomy for the treatment of pericardial effusion in dogs. $\mathrm{J}$ Am Vet Med Assoc, 242, 493-8.

10. Chun R, Kellihan HB, Henik RA, et al. (2010): Comparison of plasma cardiac troponin I concentrations among dogs with cardiac hemangiosarcoma, noncardiac hemangiosarcoma, other neoplasms, and pericardial effusion of nonhemangiosarcoma origin. J Am Vet Med Assoc, 237, 806-11.
11. Côté E, Schwarz LA, Sithole F (2013): Thoracic radiographic findings for dogs with cardiac tamponade attributable to pericardial effusion. J Am Vet Med Assoc, 243, 232-5.

12. Dunning D, Monnet E, Orton C, et al. (1998): Analysis of prognostic indications for dogs with pericardial effusion: 46 cases (1985-1996). J Am Vet Med Assoc, 212, 1279-1280.

13. Guglielmini C, Diana A, Santarelli G, et al. (2012): Accuracy of radiographic vertebral heart score and sphericity index in the detection of pericardial effusion in dogs. J Am Vet Med Assoc, 241, 1048-55.

14. MacGregor JM, Faria ML, Moore AS, et al. (2005): Cardiac lymphoma and pericardial effusion in dogs: 12 cases (1994-2004). J Am Vet Med Assoc, 227, 1449-1453.

15. Olivier NB (2002): ECG of the month. J Am Vet Med Assoc, 1154-1155.

16. Pepi M, Muratori M (2006): Echocardiography in the diagnosis and management of pericardial disease. $\mathrm{J}$ Cardiovasc Med, 7, 533-544.

17. Root C, Bahr R (1994): The heart and great vessels. 316317. In: D Thrall (Ed), Textbook of Veterinary Diagnostic Radiology. WB Sounders Co., Philadelphia.

18. Scollan K.F, Bottorff B, Stieger-Vanegas S, et al. (2015): Use of Multidetector Computed Tomography in the Assessment of Dogs with Pericardial Effusion. J Vet Intern Med, 29, 79-87.

19. Serres FJ, Chetboul V, Tissier R, et al. (2006): Doppler echocardiography-derived evidence of pulmonary arterial hypertension in dogs with degenerative mitral valve disease: 86 cases (2001-2005). J Am Vet Med Assoc, 229, 1772-1778.

20. Shoemaker W (2000): Pericardial tamponade. 10971101. In: A. Grevnik (Ed), Textbook of Critical Care. WB Saunders Co., Philadelphia.

21. Sisson A, Thomas WP, Ruehl WW, et al. (1984): Diagnostic value of pericardial fluid analysis in the dog. $\mathrm{J}$ Am Vet Med Assoc, 184, 51-55.

22. Sisson D, Thomas W (1999): Pericardial disease. 668669. In: PR Fox, NS Moise (Eds), Textbook of Canine and Feline Cardiology Principles and Clinical Practice - II. W.B. Sounders Co., Philadelphia.

23. Stephen R, Withley N, Dubielzig R (2000): Idiopathic or mesothelioma-related pericardial effusion: Clinical findings and survival in 17 dog studied retrospectively. $\mathrm{J}$ Small Anim Pract, 41, 342-347.

24. Witt A, Mathews K (2000): Successful management of traumatic right atrial rupture. J Vet Emerg Crit Care, 10, 85-89.

Geliş tarihi: 02.03.2015 / Kabul tarihi: 08.07.2015
Address for correspondence : Zeki YILMAZ, DVM, PhD, Prof.
Uludağ University,
Faculty of Veterinary Medicine,
Department of Internal Medicine,
Animal Hospital,
Bursa, Turkey.
e-mail:zyilmaz@uludag.edu.tr 